\title{
Ultrasonographic and Color Doppler Ultrasonographic Parameters to Discriminate Thyroid Nodules
}

\author{
Tiroid Nodüllerinde Ultrasonografi ve Renkli Doppler Ultrasonografi Bulguları Birlikteliğinde Malignite \\ Saptanması
}

Ayșegül Gürsoy Çoruh¹, Zehra Akkaya' ${ }^{1}$ Derya Öztuna², Suat Kemal Aytaç', Serdar Akyar

Ankara Üniversity, School of Medicine, Department of Radiology 2 Ankara University, Scholl of Medicine, Department of Biostatistics
Received: April 16,2016 • Accepted: Aug 22,2016

\section{Corresponding autho}

Aysegul Gursoy Coruh, M.D.

\section{E-posta:draysegulgursoy@gmail.com,} draysegulgursoy@hotmail.com

Phone: +905054007716

Phone: +905054007716 Department of Radiology, Sihhiye/Ankara/ Turkey
Objective: To determine parameters that can be used to predict malignant thyroid nodules by using grayscale ultrasonography and color Doppler ultrasonography

Materials-methods: Gray-scale ultrasonography and color Doppler ultrasonography findings were retrospectively analyzed in 60 nodules with known histopathology. Of 60 nodules, 12 nodules were malignant The evaluation criteria for gray-scale ultrasonography were: size, echotexture, internal morphology, contour, presence of microcalcification, and presence of halo sign. The evaluation criteria for color Doppler ultrasonography were: vascular flow pattern and resistive index. Vascular flow patterns were classified as Types I, II, III, and IV.

Results: Irregular contour and type IV flow patterns were the most significant independent predictors of malignancy in malignant thyroid nodules. Resistive index was significantly higher in malignant nodules. The cut off value was established as resistive index $\geq 0.69 ; 91 \%$ sensitivity and $97 \%$ specificity were calculated in the identification of malignant nodules. A combination of the absence of a halo sign, type IV flow pattern, and irregular contour had the highest specificity and positive predictive value $(66.7 \%$ sensitivity, $100 \%$ specificity, $100 \%$ positive predictive value, $92.3 \%$ negative predictive value).

Conclusion: We believe that by the integration gray-scale ultrasonography with color Doppler ultrasonography findings, it is possible to determine which nodule is malign/benign without performing fine needle aspiration biopsy (FNAB) and unnecessary operations could be prevented.

Key Words: Thyroid Nodule, Ultrasonography, Doppler Ultrasonography, Resistive Index, Vascularization

Amaç: Tiroid nodüllerinde ultrasonografi bulgularına ek olarak renkliDoppler ultrasonografi bulguları ile birlikte malign - benign ayrımını yapabilmek

Materyal - Metod: Çalıșmamızda total yada subtotaltiroidektomi sonucunda patolojileri bilinen 60 nodül incelenmiștir. Retrospektif olarak 60 nodülün 12'si malign karakterdeydi. Nodüllerde ultrasonografi bulguları olarak; boyut, ekojenite, natür, kenar yapısı, mikrokalsifikasyon varlığı, periferikhalo varlığı değerlendirilmeye alındı. Renkli Doppler ultrasonografi bulguları olarak kanlanma desenlerine ve rezistif indeks değerlerine bakıldı. Kanlanma desenleri 4 sınıfta gruplandırıldı; tip I, tip II, tip III, tip IV .

Bulgular: Düzensiz kenar yapısı ve tip IV kanlanma deseni malignnodül saptamada en özgül bağımsız parametreler olarak saptandı. Rezistif indeks değeri malignnodüllerde daha yüksek bulundu. Rezistif indeks için cutoff değeri \% 91 duyarlılık ve \% 97 özgülük ile 0,69 olarak hesaplandı. Düzensiz kenar yapısı, periferikhalo kaybı ve tip IV kanlanma deseni kombinasyonu malignnodül saptamada en özgül ve en yüksek pozitif tahmini değere sahip bulgu olarak bulundu (\% 66.7 duyarlılık, \%100 özgüllük, \%100 pozitiftahminideğer, $\% 92.3$ negatif tahmini değer).

Sonuç: Ultrasonografik ile renkli Doppler ultrasonografi bulguları birlikte malign - benign nodül ayrımı yapılabilir ve gereksiz cerrahi ișlem engellenilebilir.

Anahtar Sözcükler: Tiroid Nodülü, Ultrasonografi, Renkli Doppler Ultrasonografi, Rezistif indeks, internal Kanlanma

Thyroid nodules are the most common thyroid disease with increasing prevalence, especially in iodine deficient areas (1). Ultrasound (US) is the primary and the most effective imaging modality in screening thyroid disease. Incidental thyroid nodules detected by US at an approximate rate of $70 \%$ of the population and detected by autopsy at a rate of approximately $50 \%$ in adults.(2). A great majority of thyroid nodules are benign. Approximately $4-14 \%$ nodules are malignant.(3).

In the literature, several studies reported that the most efficient method in discriminating between benign and malignant nodules is fine needle aspiration biopsy (FNAB) with a sensitivity of $65-98 \%$ and specificity of 72-100\%.(4). Even in large, 
experienced centers inadequate specimen and non-diagnostic cytology rate is up to $15-20 \% \quad(5,6)$. Furthermore, false negative results are reported at a range of $3-21 \%$.(7). Consequently, a non-invasive, safe, and low cost diagnostic procedure is required, with high accuracy, to discriminate malignant and benign thyroid nodules. Several gray-scale US and color Doppler ultrasonography (CDUS) features have been reported to be highly suggestive of malignancy such as hypoechogenicity, presence of microcalcification, irregular contour, hypervascular central flow, and high Resistive Index (RI) (3,8,9). On the contrary, several authors claim that there are no correlations with the central flow, echogenicity, shape, and malignancy $(9,11)$.

The purpose of this study is to evaluate the capabilities of gray-scale US and CDUS alone and in combination, in detecting malignant thyroid nodules. Furthermore, this study also aimed to determine which thyroid nodule should receive surgery using the US and CDUS parameters without performing FNAB.

\section{Materials and Methods}

The researchers of the current study retrospectively reviewed the records of patients who were underwent surgical intervention between the years 2004 and 2009. Thirty patients' (median age: $42.37 \pm 10.10$ years; range: 25-61), consisting of 24 women (80\%) and 6 men $(20 \%)$, gray-scale US and CDUS data were evaluated by one radiologist. Sixty nodules were included in the study. Each nodule was reported as benign or malignant nodule based on histologic classification. Out of 60 nodules, $48(80 \%)$ nodules were benign and $12(20 \%)$ nodules were malignant. All US and CDUS were conducted by the same radiologist with more than ten years of experience in thyroid ultrasound. Sonography was performed using the Sonoline Antares system (Siemens, Washington, USA) using 4-9 $\mathrm{mHz}$ and $5-13 \mathrm{mHz}$ linear array transducers.

The evaluation criteria for gray-scale US included: size, echotexture, internal morphology, contour, presence of microcalcification, and the presence of a halo sign. The size of the nodule was defined as the largest size in any of the three dimensions, which were measured in transverse and longitudinal planes. Microcalcification was defined as hyperechoic spots below $2 \mathrm{~mm}$ with/without acoustic shadowing and without comet artifact. Internal morphology was categorized as solid, mixed, or cystic according to the ratio of solid and cystic components. A solid nodule was defined when a nodule had a cystic component, compromising less than $25 \%$ of it and a cystic nodule was defined when a nodule consisted of more than $75 \%$ cystic spaces. Echogenicity of the nodule was identified by comparing the nodule with the thyroid parenchyma and strap muscles, and qualified as hypoechoic, hyperechoic, and isoechoic. The contour of the nodule was categorized as well-defined or spiculated/irregular. The absence or discontinuity of a peripheral halo sign was evaluated.

On CDUS, vascular flow patterns were classified as Types I, II, III, and IV.

Type I: No visible flow

Type II: Peri-nodular (peripheral) flow

Type III: Peri-nodular flow (peripheral) with minimal internal flow

Type IV: Marked internal flow (intrinsic hypervascularity) or marked internal flow with peripheral flow. Marked internal flow was qualified as flow in the central part of the tumor greater than that in the surrounding thyroid parenchyma.

Resistive index (RI) was recorded, which was performed on one to three arteries of greater caliber in a vascularized nodule. Nodules consisting of central and peripheral flow, the measurements were taken in both vascular portions. Resistive Index was automatically calculated in the software, and for all nodules, average values were obtained.

Statistical analyses were performed using SPSS 11.5. Frequency (percent) for categorical variables, mean \pm standard deviation for metric variables was given as descriptive statistics. In order to compare two independent groups in terms of categorical and metric variables, the chi-square test and Mann-Whitney U-test were used, respectively. The area under receiver operating characteristics (ROC) curve was evaluated for the examination of diagnostic performance of RI. Additionally, the sensitivity, specificity, positive predictive value (PPV), and negative predictive value (NPV) were calculated. $\mathrm{P}<0.05$ was considered statistically significant.

\section{Results}

In this study, there were $48(80 \%)$ benign and $12(20 \%)$ malignant nodules. Out of 12 malignant nodules, 11 were papillary carcinomas, 1 was a follicular carcinoma. All malignant nodules were solitary. Overall nodule size ranged from $3 \mathrm{~mm}$ to $50 \mathrm{~mm}$ with a mean value $14.87 \pm 10.54 \mathrm{~mm}$. Out of 60 nodules, $58(96.7 \%)$ were solid and 2 $(3.3 \%)$ were mixed morphology. All malignant nodules and 46 (95.8\%) benign nodules had a solid appearance. None of the nodules were in cystic in nature. There were no statistically significant differences between benign and malignant nodules regarding size $(p=0.3)$ and internal morphology $(\mathrm{p}=1)$.

Hypoechogenicity was a common grayscale US feature in malignant nodules $(91.7 \%)$, whereas for benign nodules, all three categorized echogenicity were seen. A total of 15 (31.3\%) of 48 benign nodules were hypoechoic, $19(39.6 \%)$ nodules were isoechoic, and $14(29.2 \%)$ nodules were hyperechoic. For echogenicity, statistically significant difference was found between benign and malignant nodules $(\mathrm{p}=0.001)$.

Of 12 malignant nodules, 11 nodules $(91.7 \%)$ had an absent or discontinuous peripheral halo. Ten $(83.3 \%) \mathrm{ma}-$ lignant nodules showed irregular contour, whereas irregular contour was detected in $3(6.3 \%)$ out of 48 benign nodules. Microcalcifications were detected in 7 of $12(58.3 \%)$ among the malignant nodules (Figure 1) and 4 of $48(8.3 \%)$ among the benign nodules. 
There was a statistically significant difference between benign and malignant nodules regarding the presence of microcalcifications, irregular contour, and the absence of a peripheral halo $(\mathrm{p}<0.001)$. Table 1 shows the distribution of the gray-scale ultrasonographic features related to the histology, which were found statistically significant for indicating ma-

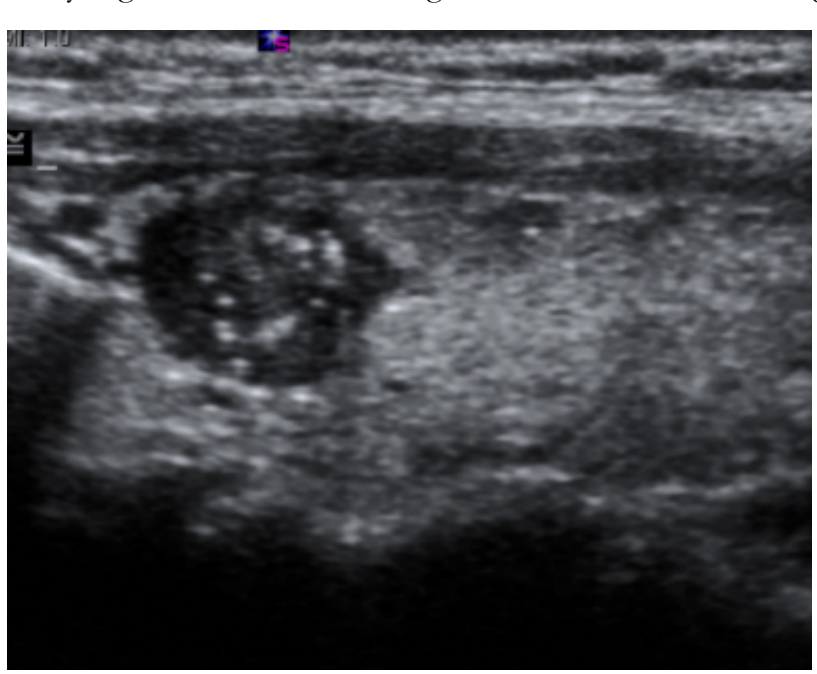

Figure 1. Microcalcifications in a hypoechoic thyroid nodule lignant thyroid nodules in this study. The gray-scale US features of hypoechogenicity, irregular contour, presence of microcalcification, and the absence of a peripheral halo were more common in malignant nodules. Comparing the gray-scale US findings, the feature with the highest specificity and positive predictive value was irregular contour (93.8\% and $76.9 \%$, respectively). Table 2 shows the comparative intragroup analysis of gray-scale US features and CDUS features between benign and malignant nodules.

A great majority of malignant nodules had internal vascular flow. A total of 8 of $12(66.7 \%)$ malignant nodules were categorized as Type IV in

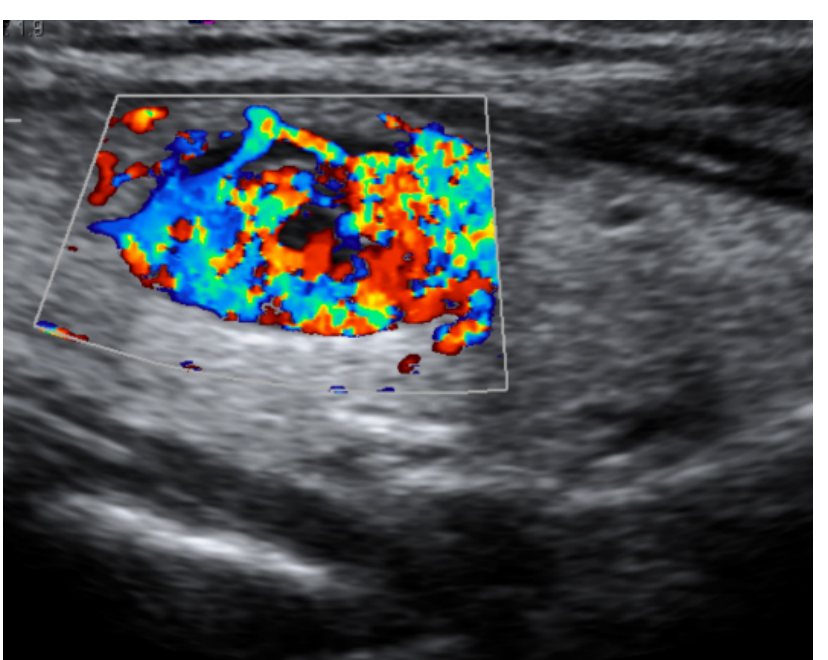

Figure 2. Type IV vascular flow pattern in papillary carcinoma with a pathological diagnosis of papillary carcinoma

Table 1: Gray-scale ultrasonographic features related to histology

\begin{tabular}{|c|c|c|c|c|c|c|c|c|c|c|}
\hline & \multicolumn{3}{|c|}{ Echogenicity } & \multicolumn{2}{|c|}{ Peripheral halo } & \multicolumn{2}{|c|}{ Contour } & \multicolumn{2}{|c|}{ Microcalsification } & \multirow{2}{*}{ Total } \\
\hline & Hyperechoic & Isoechoic & Hypoechoic & Presence & Absence & Well-defined & Irregular & Presence & Absence & \\
\hline Benign & $\begin{array}{c}14 \\
(29.2 \%)\end{array}$ & 19 (39.6\%) & $\begin{array}{c}15 \\
(31.3 \%)\end{array}$ & 41 (85.4\%) & $7(14.6 \%)$ & 45 (93.8\%) & $\begin{array}{c}3 \\
(6.3 \%)\end{array}$ & $\begin{array}{c}4 \\
(8.3 \%)\end{array}$ & 44 (91.7\%) & 48 \\
\hline Malignant & $\begin{array}{c}1 \\
(8.3 \%)\end{array}$ & $\begin{array}{c}0 \\
(0 \%)\end{array}$ & $\begin{array}{c}11 \\
(91.7 \%)\end{array}$ & $\begin{array}{c}1 \\
(8.3 \%)\end{array}$ & 11 (91.7\%) & $2(16.7 \%)$ & $10(83.3 \%)$ & $7(58.3 \%)$ & 5 (41.7\%) & 12 \\
\hline
\end{tabular}

Table 2: Diagnostic data for gray-scale ultrasound and color Doppler ultrasound features of malignant nodules

\begin{tabular}{|c|c|c|c|c|c|c|}
\hline & Malignant \% & $\begin{array}{c}\text { Benign } \\
\%\end{array}$ & $\begin{array}{c}\text { Sensitivity } \\
\%\end{array}$ & $\begin{array}{c}\text { Specificity } \\
\%\end{array}$ & Positive predictive value $\%$ & $\begin{array}{c}\text { Negative predictive } \\
\text { value } \%\end{array}$ \\
\hline Hypoechogenicity & 91.7 & 31.3 & 91.6 & 68.7 & 42.3 & 97 \\
\hline Absence of peripheral halo & 91.7 & 14.6 & 91.7 & 85.4 & 61.1 & 97.2 \\
\hline Irregular contour & 83.3 & 6.3 & 83.3 & 93.8 & 76.9 & 95.7 \\
\hline Presence of microcalcification & 58.3 & 8.3 & 58.3 & 91.7 & 63.6 & 89.8 \\
\hline Type IV flow pattern & 66.7 & 16.7 & 66.7 & 83.3 & 50 & 90.9 \\
\hline
\end{tabular}

Table 3: Distribution of the types of flow patterns among benign and malignant nodules

\begin{tabular}{|c|c|c|c|}
\hline & Benign & Malignant & Total \\
\hline Type I flow pattern & $6(12.5 \%)$ & $0(0 \%)$ & $6(10 \%)$ \\
\hline Type II flow pattern & $15(31.3 \%)$ & $0(0 \%)$ & $15(25 \%)$ \\
\hline Type III flow pattern & $19(39.6 \%)$ & $4(33.3 \%)$ & $23(38.3 \%)$ \\
\hline Type IV flow pattern & $8(16.7 \%)$ & $8(66.7 \%)$ & $16(26.7 \%)$ \\
\hline Total & 48 (80\%) & 12 (20\%) & 60 (100\%) \\
\hline
\end{tabular}


CDUS (Figure 2). In the current study, none of the malignant nodules showed Type I or Type II flow pattern. Table 3 shows the distribution of the types of flow patterns among benign and malignant nodules. Among the other types of flow pattern, Type IV presented highest specificity and sensitivity $(83.3 \%$ and $66.7 \%$, respectively) with a $50 \%$ positive predictive value and a $90.9 \%$ negative predictive value.

RI was significantly higher in malignant nodules (Figure 3). The mean value of RI was $0.80 \pm 0.15$ (range: $0.50-1$ ) in ma- lignant nodules and $0.52 \pm 0.06$ (range: $0.45-0.77$ ) in benign nodules. Among the benign nodules, the highest RI ( $\mathrm{RI}=0.77$ ) was detected in follicular adenoma. The best results were calculated for a $\mathrm{RI} \geq 0.69$ cut off value, with $91 \%$ sensitivity and $97 \%$ specificity in discriminating malignant nodules.

We also evaluated a combination of grayscale US features and CDUS features for discriminating malignant nodules (Table 4). The absence of a peripheral halo, irregular contour, and Type IV flow pattern indicated the highest specificity $(100 \%)$ and positive predictive value $(100 \%)$ to predict ma-

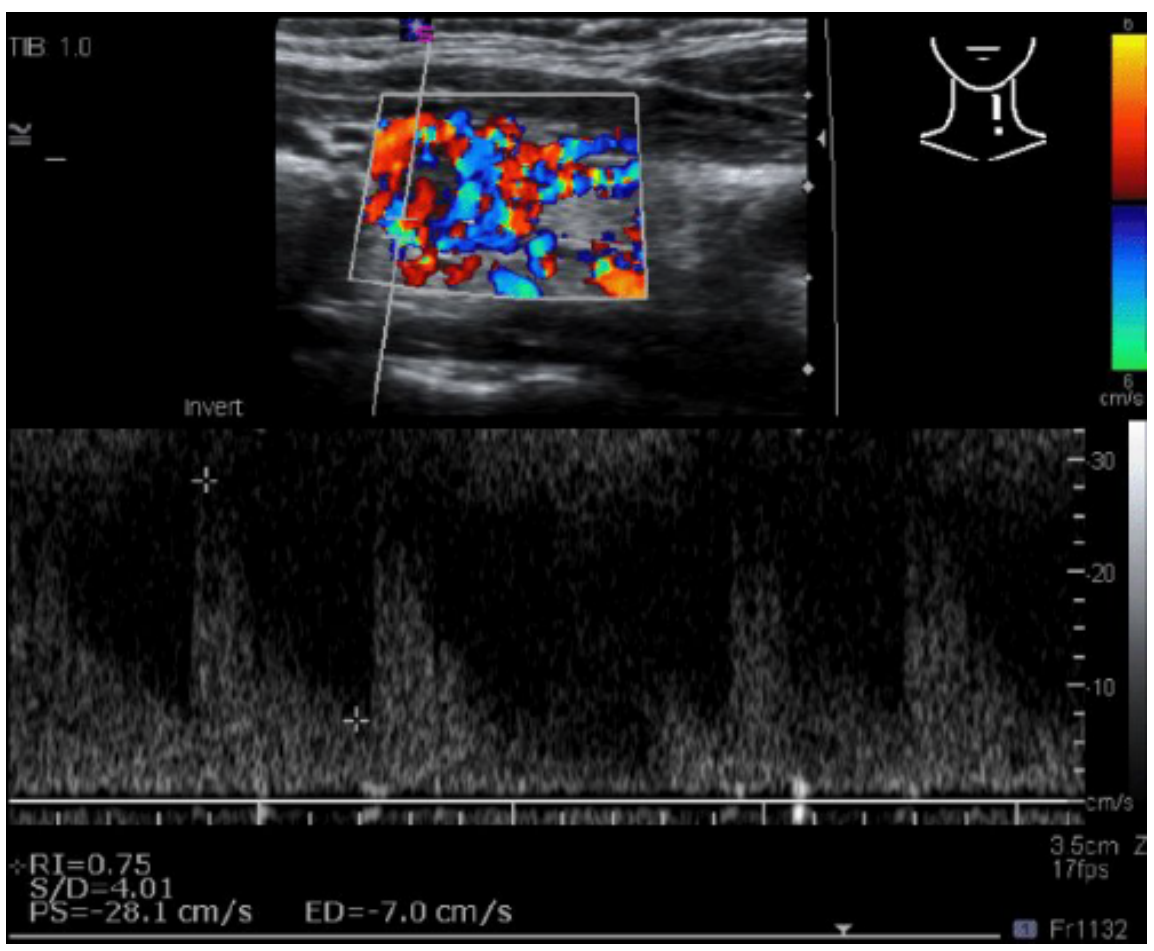

Figure 3. Spectral analysis of arterial vascularity shows a high resistance waveform with a RI value of 0.75 . This nodule had a diagnosis of papillary carcinoma. lignancy with a $66.7 \%$ sensitivity and $92.3 \%$ negative predictive value.

\section{Discussion}

Nodular thyroid disease is very common and a great majority of nodules are benign. Thyroid cancer prevalence ranges from $1.5 \%$ to $10 \%$ (12). Although thyroid malignancy is rare, it is important to discriminate malignant from benign nodules because it is one of the most curable malignancy. Furthermore, early and accurate diagnosis could alter the therapeutic approach (13). Thyroid US is the most prevalent method to detect and characterize the thyroid nodules. There are a great number of studies discussing the sonographic and Doppler findings for thyroid nodules in the literature, yet there is no common consensus. The current study demonstrated that the integration of CDUS and gray-scale ultrasound findings improved the specificity and positive predictive value in identifying malignant nodules.

In the current study, no statistically significant difference was found in predicting malignancy according to nodule size and morphology $(p=0.3, p=1$, respectively). Twelve $(100 \%)$ malignant nodules and $46(95.8 \%)$ benign nodules had a solid appearance. Likely for the benign nodules, the mean nodule size was $14.67 \pm 11.07 \mathrm{~mm}$, and for the malignant nodules the mean nodule size was $15.68 \pm 8.4 \mathrm{~mm}$. The results of the current study supported the findings in the literature. Previous researchers similarly declared that nodule size and internal morphology were not predictive of malignancy $(14,18)$.

Table 4:Gray-scale ultrasound and color Doppler ultrasound combination features related to malignant histology in thyroid nodules

\begin{tabular}{|l|c|c|c|c|}
\hline & Sensitivity $\%$ & Specificity $\%$ & $\begin{array}{c}\text { Positive predictive } \\
\text { value \% }\end{array}$ & $\begin{array}{c}\text { Negative predictive } \\
\text { value \% }\end{array}$ \\
\hline Hypoechogenicity+ type IV flow pattern & 66.7 & 93.8 & 72.7 & 91.8 \\
\hline Presence of microcalcification+ type IV flow pattern & 41.7 & 97.9 & 83.3 & 87 \\
\hline Absence of peripheral halo +type IV flow pattern & 66.7 & 93.8 & 72.7 & 91.8 \\
\hline $\begin{array}{l}\text { Absence of peripheral halo+irregular contour+ type IV flow } \\
\text { pattern }\end{array}$ & 66.7 & 100 & 100 & 92.3 \\
\hline $\begin{array}{l}\text { Absence of peripheral halo+ presence of microcalcification } \\
\text { +type IV flow pattern }\end{array}$ & 41.7 & 97.9 & 83.3 & 87 \\
\hline $\begin{array}{l}\text { Hypoechogenicity + absence of peripheral halo +type IV } \\
\text { flow pattern }\end{array}$ & 66.7 & 93.8 & 72.7 & 91.8 \\
\hline
\end{tabular}


Hypoechogenicity was a common grayscale US feature in malignant nodules $(12,18,19)$. In the current study, a total of 11 of 12 malignant nodules were hypoechoic. Benign nodules' echogenicities were variable. In this study hypoechogenicity is a valuable gray-scale US marker with a sensitivity of $91.6 \%$ and specificity of $68.7 \%$. Hypoechogenicity was also frequently seen in benign nodules; therefore its specificity was the lowest in the grayscale ultrasonographic criteria.

There was a statistically significant difference between benign and malignant nodules regarding the presence of microcalcifications ( $p<0.001$ ). Kim et al. (17) demonstrated that the presence of microcalcification is the most sensitive gray-scale US criteria in their study. Presence of microcalcification has a high specificity of $91.7 \%$, which was the second highest specific finding in gray-scale US, sensitivity however was relatively lower compared to other findings that suggest malignancy such as contour abnormality and hypoechogenicity which may have resulted from lownumber of patients included in the study. Similarly, Moon et al. (12) declared that the presence of microcalcification can be considered as a highly specific finding for malignancy. The current findings are in concordance with their study.

In previous studies, a great majority of authors reported the association between the absence of a complete peripheral halo and malignancy $(15,16,20,21)$. A peripheral halo is composed of compressed thyroid parenchyma and prominent vessels. In agreement with these reports, in the current study of 12 malignant nodules, 11 nodules $(91.7 \%)$ had absent or discontinuous peripheral halo. An absent halo sign is the most sensitive parameter in the current study with a sensitivity of $91.7 \%$, but it is less specific. In predicting malignancy with gray-scale ultrasound features, irregular/spiculated contour is the best single parameter with a specificity of $93.8 \%$, sensitivity of $83.3 \%$, positive predictive value of $76.9 \%$, and negative predictive value of $95.7 \%$.
CDUS examination has become a considerable imaging technique for discriminating malignant and benign thyroid nodules. Regarding CDUS findings, some vascular patterns were classified to differentiate benign and malignant nodules. In previous studies, many authors have shown the association between the increased intranodular blood flow and malignancy $[3,9,19,22,23]$. According to the data of the current study, increased intranodular blood flow (Type IV) was a statistically significant criterion to suggest malignancy $(p=0.001)$. Tamsel et al. [24] and Algin et al. [25] did not find any relationship between high intranodular blood flow and malignancy .It is assumed that technical issues (settings of a wall filter and pulse repetition frequency) and patients lack of cooperation (breathingswallowing motion artifacts) may have hidden the possible relationship between intranodular vascularity and malignancy in these studies.

In addition to vascular patterns, there are several studies that have shown the relationship with the histology of the thyroid nodules and vascular resistance $[3,5,13,19,26]$. RI is a good spectral Doppler parameter for evaluating thyroid nodules because it is not dependent on the angle of insonation. In the literature, many authors declared that RI values in malignant nodules were higher than in benign nodules $[3,5,19,23,26]$. Ivanac et al. [3] calculated the optimal cut-off value as $\mathrm{RI} \geq 0.70$ to distinguish malignant nodules from benign nodules with a sensitivity of $80 \%$ and specificity of $92 \%$. De Nicola et al [5], Holden [19], and Cerbone et al. [13] reported similar results and found mean RI values for carcinomas of $0.75,0.76$, and 0.75 , respectively. These studies suggested that large quantities of stenosis and occlusions in the neovascularization of differentiated thyroid carcinomas lead to an increase in vascular resistance. Similarly, in the current study, RI was significantly higher in malignant nodules $(0.80 \pm 0.15$ vs. $0.52 \pm 0.06)$ and $\mathrm{RI} \geq 0.69$ was highly suggestive of malignancy with a sensitivity of $91 \%$ and specificity of $97 \%$. However, Tamsel et al. [24] reported poor sensitivity and specificity values of $11 \%$ and $4 \%$, respectively, for an RI cut-off of 0.75 . The study of Tamsel et al. [24] was based on cytological results acquired by FNAB. False negative results could arise in some cases, which might have potentially altered the results of this study.

In the literature, they also analyzed grayscale US and CDUS features in combination and reported increased specificity by combining CDUS and US in the detection of malignancy in thyroid nodules $[9,15,16]$. In the current study with the combination parameters (Table 4), there was an improvement in specificity and positive predictive value. On the contrary, Stacul et al. [8] did not report an improvement in diagnostic performance of malignant thyroid nodules. This disagreement may be related, using the cytology as the reference standard, and therefore the results could be deviated. In the current study, among the associations of several US patterns with CDUS; the absence of a peripheral halo, irregular contour, and Type IV flow pattern is the most valuable combination with a specificitiy of $100 \%$, sensitivity of $66.7 \%$, positive predictive value of $100 \%$, and negative predictive value of $92.3 \%$.

There are some limitations in this study. Firstly, the number of the patients that were included in the study was limited. Secondly, a great majority of the malignant nodules were papillar carcinoma. Additional studies should be performed with a larger population including other types of thyroid malignancies. The strength of this study was that all nodules in this study had histological reports obtained from surgical specimens.

In conclusion, the results of present study indicate that CDUS gave an incremental value to gray-scale US in the diagnosis of malignant thyroid nodules. Due to the high specificity and positive predictive value, the findings of combined CDUS and gray-scale US features can determine malignant thyroid nodules and patients with such nodules may undergo surgery without the need of FNAB. 


\section{REFERENCES}

1. Belfiore A, Rosa GL, Giuffrida D, et al. The management of thyroid nodules. J Endocrinol Invest. 1995; 18: 155-158

2. Alexander EK, Hurwitz S, Heering JP, et al. Natural history of benign solid and cystic thyroid nodules. Ann Intern Med. 2003; 138: 315-318

3. Ivanac G, Brkljacic B, Ivanac $K$, et al. Vascularisation of benign and malignant thyroid nodules: CD US evaluation. Ultraschall Med. 2007;28:502-506.

4. Gharib H. Fine-needle aspiration biopsy of thyroid nodules: advantages, limitations, and effect. Mayo Clin Proc 1994;69:44-49.

5. De Nicola H, Szejnfeld J, Logullo AF, et al. Flow pattern and vascular resistive index as predictors of malignancy risk in thyroid follicular neoplasms. J Ultrasound Med. 2005;24:897-904.

6. Gharib H, Goellner JR. Fine-needle aspiration biopsy of the thyroid: an appraisal. Ann Intern Med. 1993;118:282289.

7. Wu HH, Jones JN, Osman J. Fine-needle aspiration cytology of the thyroid: ten years experience in a community teaching hospital. Diagn Cytopathol. 2006;34:9396.

8. Stacul F, Bertolotto M, De Gobbis F, et al. US, colour-Doppler US and fineneedle aspiration biopsy in the diagnosis of thyroid nodules. Radiol Med. 2007;112:751-762

9. Rago T, Vitti P, Chiovato L, et al. Role of conventional ultrasonography and color flow-doppler sonography in predicting malignancy in 'cold' thyroid nodules. Eur J Endocrinol. 1998;138:41-46.
10. Iannuccilli JD, Cronan JJ, Monchik JM. Risk for malignancy of thyroid nodules as assessed by sonographic criteria: the need for biopsy. J Ultrasound Med. 2004;23:1455-1464.

11. Shimamoto K, Endo T, Ishigaki T, et al. Thyroid nodules: evaluation with color Doppler ultrasonography. J Ultrasound Med. 1993;12:673-678.

12. Kim SJ, Moon WK, Cho N. Sonographic criteria for fine-needle aspiration cytology in a Korean female population undergoing thyroid ultrasound screening. Acta Radiol. 2010;51:475-481.

13. Cerbone G, Spiezia S, Colao A, et al. Power Doppler improves the diagnostic accuracy of color Doppler ultrasonography in cold thyroid nodules: follow-up results. Horm Res. 1999;52:19-24.

14. Ginat DT, Butani D, Giampoli EJ, et al. Pearls and pitfalls of thyroid nodule sonography and fine-needle aspiration. Ultrasound Q. 2010;26:171-178.

15. Phutharak W, Somboonporn C, Hongdomnern G. Diagnostic performance of gray-scale versus combined gray-scale with colour doppler ultrasonography in the diagnosis of malignancy in thyroid nodules. Asian Pac J Cancer Prev. 2009;10:759-764.

16. Appetecchia M, Solivetti FM. The association of colour flow Doppler sonography and conventional ultrasonography improves the diagnosis of thyroid carcinoma. Horm Res. 2006;66:249-256.

17. Kim EK, Park CS, Chung WY, et al. New sonographic criteria for recommending fine-needle aspiration biopsy of nonpalpable solid nodules of the thyroid. AJR Am J Roentgenol. 2002;178:687-691.
18. Frates MC, Benson CB, Doubilet PM, et al. Prevalence and distribution of carcinoma in patients with solitary and multiple thyroid nodules on sonography. J Clin Endocrinol Metab. 2006;91:3411-3417.

19. Holden A. The role of colour and duplex Doppler ultrasound in the assessment of thyroid nodules. Australas Radiol. 1995; 39:343-349.

20. Koike E, Noguchi S, Yamashita H, et al. Ultrasonographic characteristics of thyroid nodules: prediction of malignancy. Arch Surg. 2001;136:334-337.

21. Moon WJ, Jung SL, Lee JH, et al. Benign and malignant thyroid nodules: US differentiation-multicenter retrospective study. Radiology 2008;247:762-770.

22. Chammas MC, Gerhard R, de Oliveira IR, et al. Thyroid nodules: evaluation with power Doppler and duplex Doppler ultrasound. Otolaryngol Head Neck Surg. 2005;132:874-882.

23. Bianek-Bodzak A, Zaleski K, Studniarek $\mathrm{M}$, et al. Color Doppler sonography in malignancy of thyroid nodules. J Ultrasound Med. 2003;22: 758

24. Tamsel S, Demirpolat G, Erdogan M, et al. Power Doppler US patterns of vascularity and spectral Doppler US parameters in predicting malignancy in thyroid nodules. Clin Radiol. 2007;62:245-251.

25. Algin O, Algin E, Gokalp G, et al. Role of duplex power Doppler ultrasound in differentiation between malignant and benign thyroid nodules. Korean J Radiol. 2010;11:594-602.

26. Frates MC, Benson CB, Doubilet PM, et al. Can color Doppler sonography aid in the prediction of malignancy of thyroid nodules? J Ultrasound Med.2003;22:127131. 